\title{
Graves' disease and Hashimoto's thyroiditis in monozygotic twins: case study as well as transcriptomic and immunohistological analysis of thyroid tissues
}

\author{
G Aust, K Krohn ${ }^{1}$, N G Morgenthaler ${ }^{6}$, S Schröder ${ }^{2}$, A Schütz ${ }^{3}$, J Edelmann ${ }^{4}$ and E Brylla ${ }^{5}$ \\ Research Laboratories, Center of Surgery, ${ }^{1}$ Interdisciplinary Center for Clinical Research (IZKF), and Institutes of ${ }^{2}$ Transfusion Medicine, ${ }^{3}$ Pathology, \\ ${ }^{4}$ Legal Medicine and ${ }^{5}$ Anatomy, University of Leipzig, Liebigstr. 20, Leipzig, 04103, Germany and ${ }^{6}$ Leipzig Research Department, B.R.A.H.M.S AG, \\ Berlin, Germany \\ (Correspondence should be addressed to G Aust; Email: ausg@medizin.uni-leipzig.de)
}

\begin{abstract}
Objective: To report on the rare simultaneous occurrence of Graves' disease (GD) and Hashimoto's thyroiditis (HT) in monozygotic twins.

Design: We compared the pattern of thyroid tissue-derived cDNAs to gain insight into previous and ongoing immune destruction and reconstruction processes using microarrays. The results were confirmed by immunohistology and real-time PCR.

Results: Destruction of thyroid tissue in HT reduced levels of thyrocyte-related cDNAs and cDNAs encoding extracellular matrix components, but increased levels of proteases involved in extracellular matrix degradation compared with GD. Lymphocytic infiltrates forming ectopic follicles replaced the thyroid tissue almost completely in HT. Thus, lymphocyte-related cDNA levels were higher in HT than in GD. The same was true for many chemokines and their receptors, which not only enable migration towards the thyroid but also maintain the lymphocytic infiltrate. HT also showed increased levels of cDNAs encoding molecules related to apoptosis than did GD. Surprisingly, the Th1- and Th2-specific cytokine profiles suggested for HT and GD respectively could not be confirmed. cDNAs encoding factors and receptors involved in angiogenesis were increased in GD compared with HT.

Conclusions: Comparison of gene expression reflects the cellular differences between the two types of autoimmune thyroid disease in twins with identical genetic and similar environmental background.
\end{abstract}

European Journal of Endocrinology 154 13-20

\section{Introduction}

Autoimmune thyroid disease (AITD) manifests itself in various clinical forms such as classical Hashimoto's thyroiditis (HT) and Graves' disease (GD). Histologically, HT and GD are both characterized by lymphocytic infiltration. However, this infiltration varies in quantitative as well as qualitative respects, possibly reflecting the different underlying pathogenic mechanisms of the two diseases (1). In HT, lymphocytic infiltrates replace thyroid follicles, resulting in a loss of hormone-producing cells and thus hypothyroidism. The follicles remain intact in GD. Here, stimulating autoantibodies against the thyroid-stimulating hormone receptor TSHR (thyroid stimulating antibodies, TSAbs) are the direct cause of hyperthyroidism.

Although GD and HT have very different phenotypes and the mechanisms leading to the dichotomy of GD and HT are unknown, they are generally believed to share a number of common etiological factors. GD and HT frequently occur in the same family; some individuals progress from one form to another. Whole-genome linkage studies on multiplex families with AITD have shown that multiple genes are responsible for a predisposition towards GD and HT, and that some are common to both diseases and some are unique (2). Although rare, there have been reports on monozygotic twins in which one twin had GD and the other had HT (3-6).

Studies on twins help in understanding the close relationship between various forms of AITD and reveal the genetic influence on its development (7-9). The relatively low concordance in monozygotic twins indicates that AITD requires non-heritable etiological determinants as well. Environmental and hormonal factors are shown to be associated with increased risk of developing AITD in genetically predisposed individuals (10; reviewed in Prummel et al. (11)).

In the present study, we have examined thyroid tissues excised from a pair of monozygotic twins, one of whom had GD and the other HT, and compared tissue-derived cDNA patterns by microarray to gain 
an insight into the past and present immune destruction and reconstruction processes in the thyroid. Since the thyroid tissues were removed on the same day, not only the genetic background but also age and processing of the thyroid were the same, which compensates for the disadvantage of analyzing only one typical case of HT compared with GD.

\section{Materials and methods}

\section{Patients and assays}

The monozygotic twin sisters were 18 years old on the day of surgery. GD and HT were diagnosed on the basis of clinical, biochemical and histological characteristics as well as by scintiscan. Thyroid dysfunction was confirmed by measurements of serum thyroid-stimulating hormone (TSH), free thyroxine $\left(\mathrm{fT}_{4}\right)$ and free triiodothyronine $\left(\mathrm{fT}_{3}\right)$. TSH binding inhibiting immunoglobulin (TBII) was determined using DYNOtest TRAK human, thyroglobulin (Tg) antibodies using DYNOtest anti-Tg, and thyroperoxidase (TPO) antibodies using DYNOtest anti-TPO (all from B.R.A.H.M.S AG, Hennigsdorf/Berlin, Germany) in sera from the patients (12). TSAb detection was carried out as described by Evans et al. (13). Bovine TSH (1 mU/ml, Sigma) was added for thyroid blocking antibody (TBAb) detection (14).

The thyroid tissues were removed from the twins on the same day. Twin B's tissue sample was taken from the nodule surrounding tissue. The study was approved by the local Medical Ethics Committee.

\section{Zygosity and HLA typing}

Zygosity of the twins was evaluated by short tandem repeat (STR) typing using 16 unlinked autosomal microsatellite markers (PowerPlex16 System, Promega, Madison, WI, USA). PCR products were resolved and detected by capillary electrophoresis on an ABI Prism 3100 Avant Genetic Analyzer (Perkin Elmer, Foster City, CA, USA). Molecular typing of HLA-DRB1 and HLA-DQB1 was performed using the PCR sequencespecific primer (SSP) technique with commercial primer sets (Olerup SSP; GenoVision VertriebsgesmbH, Vienna, Austria) according to the requirements of the European Federation of Immunogenetics (EFI). HLA typing for Class I was performed by complement-dependent microlymphocytotoxicity testing.

\section{Identification of lymphocytic infiltrates and germinal centers}

Thyroid sections stained with hematoxylin and eosin (HE) were screened for focal lymphocytic infiltration (15). The ectopic follicle and germinal center areas $(n=50)$ were measured as described (1).

\section{Microarray analysis}

Total RNA was isolated from thyroid tissue using the RNeasy kit (Qiagen, Hilden, Germany). Ten micrograms were used to prepare ds cDNA (Superscript II, Life Technologies, Gaithersburg, MD, USA) primed with oligo-dT containing a T7 RNA polymerase promoter site (Genset SA, Paris, France). Phenol chloroform extraction was used to purify the cDNA before in vitro transcription using the ENZO BioArray RNA transcript labeling kit (Affymetrix, Santa Clara, CA, USA) to synthesize cRNA. The cRNA was fragmented and hybridized to Affymetrix GeneChip U95Av2. To detect differentially regulated genes, we selected genes that were characterized by the Affymetrix MAS5 software as 'increased' or 'decreased' and had a signal log ratio (SLR) $\geq 1.5$ or $\leq-1.5$ (that is, these genes are expressed at levels at least 2.828 times higher or lower in the GD than in the HT sample; arbitrarily chosen). If a certain gene is represented by more than one specific probe set on the chip, we displayed the probe set with the lowest SLR.

\section{Real time RT-PCR}

Superscript II RNaseH-reverse transcriptase (Invitrogen) was used to synthesize cDNA. Quantitative PCR was performed on a Rotorgene (Corbett Research, Mortlake, Australia) real-time machine by using SYBR Green I. The PCR primers for CXCR4, CXCL13, CD20, CD3, TPO, Tg, MMP9, and TIMP3 have been published elsewhere (15-18). The primer pair for glyceraldehyde3-phosphate dehydrogenase $(\mathrm{GAPDH})$ was sense $5^{\prime}$ GCT TTC AAT AGC ACC TTG CC-3', antisense 5'- CTG CTC ACG TCA TCA TCA GT $-3^{\prime}$.

Transcripts were quantified in three tissue samples from each patient as described (15). Data are expressed as ratio-specific cDNA:GAPDH cDNA, which was calculated from the same cDNA sample. Finally, $\log$ (2) ratios of the GD:HT data were calculated.

\section{Immunohistology}

Serial sections of thyroid tissue were cut at $6 \mu \mathrm{m}$ and fixed in ice-cold methanol for $10 \mathrm{~min}$. The sections were incubated using the monoclonal antibodies Ki67 (clone MIB1), CD45R0, CD8, CD22, laminin, collagen IV and vascular endothelial growth factor (VEGF) obtained from DakoCytomation GmbH (Hamburg, Germany), Acris Antibodies GmbH (Hiddenhausen, Germany), and Sigma-Aldrich Chemie $\mathrm{GmbH}$ (Taufkirchen, Germany). Following incubation with the antibody at $4{ }^{\circ} \mathrm{C}$ overnight, bound antibodies were detected using a super-sensitive detection kit (Dako Cytomation). 


\section{Results}

\section{Case report}

The monozygotic twin sisters were born in 1984 after an uncomplicated pregnancy. They lived in the same house until the age of fourteen. Thus, for the last four years the twins may be discordant for a number of environmental risk factors such as iodine intake, number of negative life events, and infections. Both patients were smokers (10 cigarettes/day). There may have been a family history of AITD. In 2001, the mother was diagnosed with HT (TSH $50.0 \mathrm{mU} / \mathrm{l}$, anti-TPO > $1000 \mathrm{U} / \mathrm{ml}$, TBII negative). Information on other family members was not available.

After birth, goiter was diagnosed in one of the twins (twin A; GD), which was treated with iodine. At the age of 15, hyperthyroidism was diagnosed in this twin. Endocrine orbitopathy was diagnosed three years later. Twin A was treated with methimazole (20 mg/day). Patient compliance was poor, however. Since hyperthyroidism was diagnosed in twin A, attention was given to her twin sister (twin B, HT) who was found to have mild transient hypothyroidism. A cold nodule was detected by scintiscan, which was the indication for thyroid surgery. Twin A (GD) was strongly positive for autoantibodies against the TSH receptor, which had TSAb quality, whereas no TBII was detectable in the HT patient (Table 1). Both patients' sera showed very high levels of antibodies against TPO, and were positive for antibodies to $\mathrm{Tg}$.

\section{Zygosity and HLA typing}

The short tandem repeat (STR) typing result confirmed monozygosity in the twin sisters examined. The 16 STR markers investigated yielded completely identical allele profiles (data not shown). The twins bore HLA-A 3,11,
HLA-B 7, 35 (Bw6,-), and HLA-Cw 3,7. HLA-DRB1 $* 11, * 15$ and HLADQB1*03, *06 were determined by PCR-SSP.

\section{Microarray analysis, immunohistology and real-time PCR}

The two thyroid tissues showed differences in expression for a total of 2866 transcripts; 1088 showed higher expression in the GD patient, 1778 in the HT sample. Setting a cut-off at the signal log ratio, 522 cDNAs were increased in GD and 407 were increased in HT.

\section{Thyrocytes}

Thyrocytes remain intact in GD, while normal thyroid parenchyma disappears in HT (Fig. 1a). We found cDNAs from thyrocyte-related molecules such as the TSHR, TPO, Tg, and thyrocyte transcription factors 1 (TITF1) and 2 (FOXE1) or of molecules known to be present in thyrocytes such as type I iodothyronine $5^{\prime}$ deiodinase (DIO1), at much lower levels - if present at all - in HT compared with GD tissue (Table 2). Real-time PCR results for Tg and TPO are shown as examples in Fig. 2.

\section{Thyroid stroma}

The levels of cDNAs for several collagen and laminin chains, including collagen IV (COL4), which is a component of the basal membrane, were lower in HT compared with GD tissue (Table 2). This result was confirmed by staining for collagen IV and laminin (Fig. 1g, h). On the other hand, the cDNA encoding matrix-metalloproteinase-9 (MMP9), which enables

Table 1 Patients' characteristics.

\begin{tabular}{|c|c|c|}
\hline & Twin A (GD) & Twin B (HT) \\
\hline First clinical diagnosis & GD with endocrine orbitopathy & Cold nodule \\
\hline Histological diagnosis & GD & $\mathrm{HT}$ \\
\hline Number of focal infiltrates $\left(n / 226 \mathrm{~mm}^{2}\right)$ & 60 & * \\
\hline Number of ectopic secondary follicles $\left(n / 226 \mathrm{~mm}^{2}\right)$ & 50 & 90 \\
\hline Area of a secondary follicle $(n=50$; mean \pm S.E.M. $)\left(\mathrm{mm}^{2}\right)$ & $0.197 \pm 0.002$ & $0.601 \pm 0.011$ \\
\hline Area of a germinal center $(n=50$; mean \pm S.E.M. $)\left(\mathrm{mm}^{2}\right)$ & $0.062 \pm 0.001$ & $0.263 \pm 0.006$ \\
\hline Anti-thyroperoxidase (TPO) antibodies (U/ml); cut off: $>60 \mathrm{U} / \mathrm{ml}$ & 64400 & 52000 \\
\hline Anti-thyroglobulin (Tg) antibodies (U/ml); cut off: > $>00 \mathrm{U} / \mathrm{ml}$ & 8720 & 168 \\
\hline TSH binding inhibiting immunoglobulin (TBII) (U/I); cut off: >1.5 U/I & 57.9 & 0 \\
\hline \multicolumn{3}{|l|}{ cAMP bioassay for } \\
\hline Thyroid stimulating antibodies (TSAb), stimulation index (\%), cut off: $1.5 \%$ & 32 & 0.1 \\
\hline Thyroid blocking antibodies (TBAb), inhibition index (\%), cut off: 40\% & 14 & 23 \\
\hline \multicolumn{3}{|l|}{ Thyroid hormones (three days before surgery) } \\
\hline TSH (mU/l) (norm 0.4-4.0) & $<0.002$ & 2.04 \\
\hline $\mathrm{fT}_{4}(\mathrm{pmol} / \mathrm{ml})($ norm $10.3-24.5)$ & 16.4 & 19.9 \\
\hline Treatment & Methizole 5 & None \\
\hline
\end{tabular}

* Lymphocytic infiltrates almost completely replaced the thyroid tissue. 

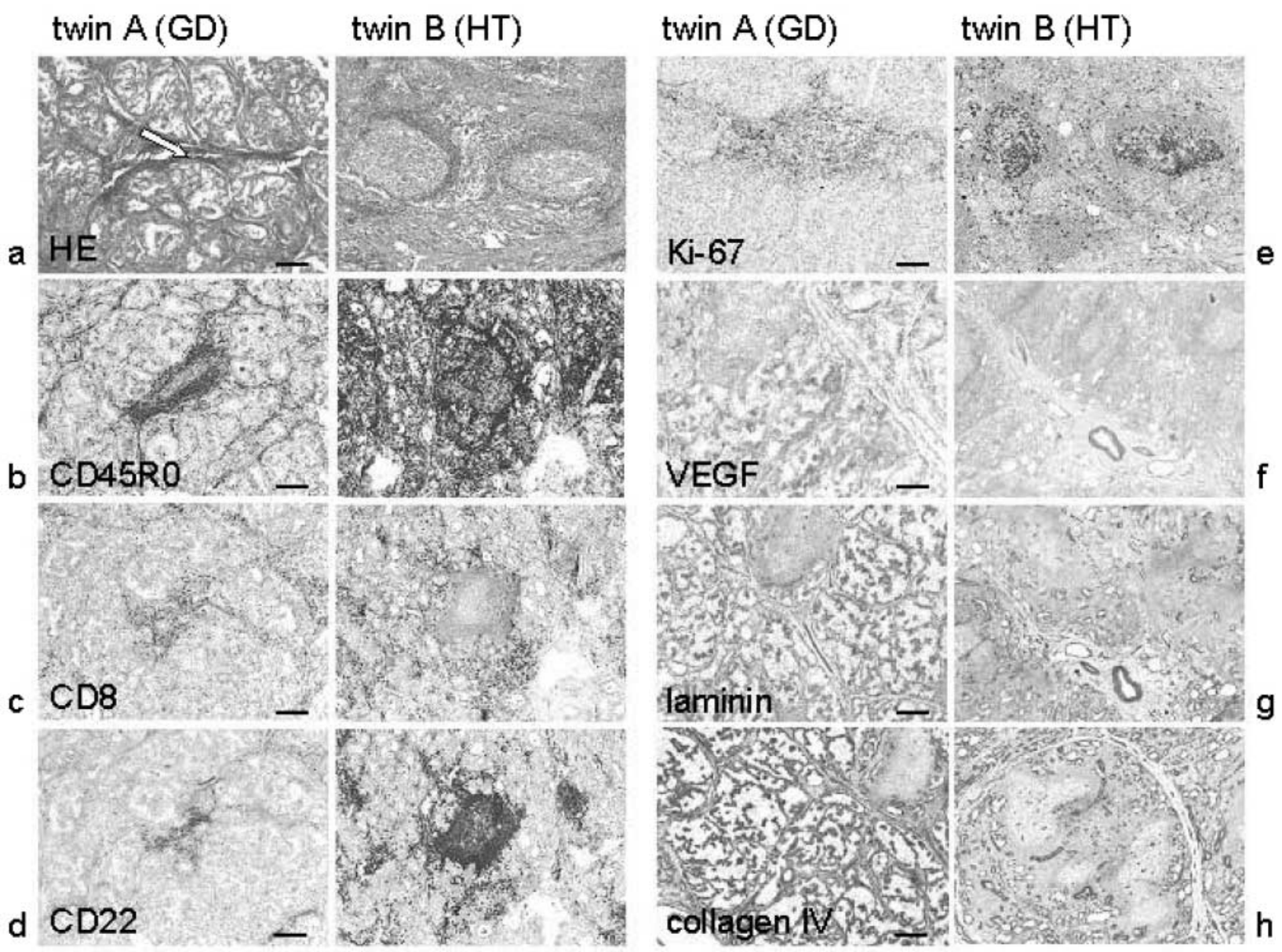

Figure 1 Pattern of cellular organization in the thyroid from monozygotic twins affected by Graves' disease (twin A, GD) and Hashimoto's thyroiditis (twin B, HT). In GD, we found focal lymphocytic infiltrates (arrow) lacking germinal center reactions and fewer as well as smaller ectopic follicles with typical germinal centers compared with the HT tissue (a). In twin B, the thyroid tissue is nearly completely replaced by lymphocytic infiltration forming many large ectopic follicles (a). Thus, more cells were labeled for CD45R0 (b), T-cell (CD8; c) and B-cell (CD22; d)-related antigens in the HT as in the GD tissue. Proliferation demonstrated here by Ki-67 staining was particularly evident in the germinal centers of secondary lymph follicles (e). VEGF expression, characteristic of higher angiogenic activity, was mainly found in the GD tissue (f). Several components of the extracellular matrix (laminin, collagen type IV; g, h) nearly disappeared in HT tissue but remained intact in GD. Scale bars: $200 \mu \mathrm{m}$ except in (e) $100 \mu \mathrm{m}$.

degradation of extracellular matrix especially collagen IV, was overexpressed in HT, whereas higher levels of TIMP3, a tissue inhibitor of MMPs, were expressed in GD. PCR results for MMP9 and TIMP3 are shown in Fig. 2. Thus, not only were thyrocytes destroyed in HT tissue, the basal membrane also disappeared (Fig. 1g, h).

\section{Intrathyroidal lymphocytes}

Lymphocytic infiltrates almost completely replaced thyroid tissue in HT (Table 1, Fig. 1a). Although lymphocytes formed ectopic follicles with germinal centers in both HT and GD tissue, they were higher in number and spread in HT than in GD tissue (Table 1). Thus, many transcripts specific for T-cells and B-cells or other molecules preferentially found in these cells, such as several cell surface receptors, transcription factors or cell signaling and activation molecules, were present at higher levels in HT than in GD tissue (data not shown). For example, only transcripts for the different CD3 and the T-cell receptor (TCR) chains are included in Table 2. As examples for increased lymphocytic accumulation in HT, the staining results for CD45R0, CD8 as a T-cell subpopulation, and $\mathrm{CD} 22$ as a B-cell marker are shown in Fig. 1b-d. PCR results for $\mathrm{CD} 3$ and CD20 are shown in Fig. 2.

\section{Chemokines and chemokine receptors}

The cDNA levels of many chemokines and their corresponding receptor(s) were much higher in HT compared with those in the GD thyroid (Table 3). For example, we found higher cDNA expression for 
Table 2 Thyrocyte, lymphocyte and extracellular matrix-related transcripts differentially expressed between HT and GD tissue $(\mathrm{SLR}=$ signal log ratio: $\geq 1.5$ or $\leq-1.5 ; \mathrm{GD}: \mathrm{HT})$.

\begin{tabular}{llr}
\hline Gene symbol & \multicolumn{1}{c}{ Gene description } & SLR \\
\hline Thyrocytes & & \\
DIO1 & Deiodinase, iodothyronine, type 1 & 6.7 \\
TPO & Thyroid peroxidase & 3.9 \\
FOXE1 & Forkhead box El (thyroid transcription factor 2) & 2.9 \\
TSHR & Thyroid stimulating hormone receptor & 2.1 \\
PAX8 & Paired box gene 8 & 1.9 \\
TG & Thyroglobulin & 1.7 \\
TITF1 & Thyroid transcription factor 1 & 1.5 \\
Lymphocytes (only some T-cell related examples shown) & -2.3 \\
CD3E & CD3E antigen, epsilon polypeptide (TiT3 complex) \\
TRA & T-cell receptor alpha locus & -2.0 \\
CD3D & CD3D antigen, delta polypeptide (TiT3 complex) & -1.8 \\
TRB & T-cell receptor beta locus & -1.7 \\
Extracellular matrix & & 3.1 \\
TIMP3 & Tissue inhibitor of metalloproteinase 3 & 2.6 \\
COL4A2 & Collagen, type IV, alpha 2 & 2.4 \\
COL18A1 & Collagen, type XVIII, alpha 1 & 1.9 \\
COL4A1 & Collagen, type IV, alpha 1 & 1.9 \\
LAMA4 & Laminin, alpha 4 & 1.7 \\
HSPG2 & Heparan sulfate proteoglycan 2 (perlecan) \\
CHI3L1 & Chitinase 3-like 1 (cartilage glycoprotein-39) \\
MMP9 & Matrix metalloproteinase 9 (92 kDa type IV collagenase) & -2.8 \\
\hline
\end{tabular}

CCR7 and its ligand, CCL19. Of the unique chemokine/chemokine receptor pairs CXCL13/CXCR5 and CXCL12/CXCR4, the transcript of one binding partner showed a signal $\log$ ratio $\geq 1.5$ (CXCL13, CXCR4; Table 3). Real-time PCR results for CXCL13 and CXCR4 are shown as examples in Fig. 2.

\section{Classical cytokines and cytokine receptors}

There were no differences in interferon (IFN)- $\gamma$ cDNA levels between the thyroid samples. Interestingly,

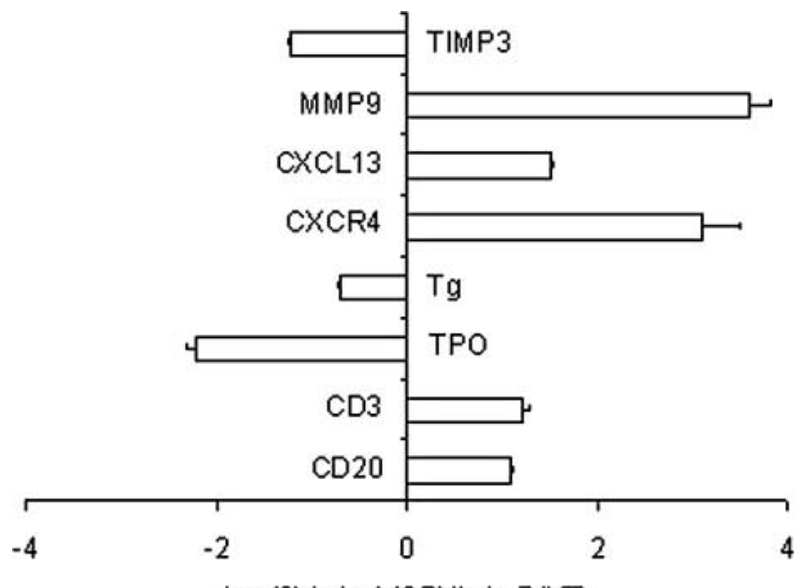

$\log (2)$ twin $A(G D) /$ twin $B(H T)$

Figure 2 Semiquantitation of eight mRNAs by real-time PCR in twin $A(G D)$ and twin $B(H T)$ tissues. Data are expressed as ratiospecific cDNA:GAPDH cDNA, which was calculated from the same cDNA sample. Finally, log (2) ratios of the GD:HT data were calculated ( $n=3$, means \pm S.E.M.). interleukin (IL)-4, IL-5, IL-10, IL-12p35, and IL-13 cDNA were absent in both thyroids. We only found differences between GD and HT tissue in some cytokine receptor cDNAs (Table 3). In most cases, these transcripts were present in the HT but not in the GD sample.

\section{Adhesion molecules}

The cDNAs of adhesion molecules involved in migration, localization and retention of lymphocytes into tissues such as CD62L (SELL), CD54 (ICAM1), and integrin $\alpha 4$ (ITGA4) were present at higher levels in HT than in GD (Table 3). However, the cDNAs of adhesion molecules known to be involved in angiogenesis such as integrin $\beta 3$ (ITGB3), integrin $\beta 5$ (ITGB5), and ephrin A3 (EPHA3) were higher in GD than in HT.

\section{Apoptosis}

The cDNAs of many apoptosis-related genes such as the key regulator caspase 3 (CASP3) were more heavily expressed in HT compared with GD (Table 4). In contrast, the cDNAs of repressors of cell death such as Bcl-2-associated athanogene 1 (BAG1) were found at higher levels in the GD thyroid.

\section{Angiogenesis}

Higher levels of VEGF-A and VEGF-C cDNAs were present in GD thyroid tissue; this was confirmed by staining for VEGF (Fig. 1f). Similarly, we found a higher cDNA level 
Table 3 Transcripts for chemokines and classical cytokines and their receptors as well as adhesion molecules differentially expressed between GD and $\mathrm{HT}$ tissue $(\mathrm{SLR}=$ signal log ratio: $\geq 1.5$ or $\leq-1.5$; GD:HT).

\begin{tabular}{|c|c|c|}
\hline Gene symbol & Gene description & SLR \\
\hline \multicolumn{3}{|c|}{ Chemokines and chemokine receptors } \\
\hline CCR6 & Chemokine (C-C motif) receptor 6 & -2.1 \\
\hline CXCL14 & Chemokine (C-X-C motif) ligand 14 & -2.1 \\
\hline CCR7 & Chemokine (C-C motif) receptor 7 & -1.9 \\
\hline CXCL13 & Chemokine (C-X-C motif) ligand 13 & -1.9 \\
\hline CCL18 & Chemokine (C-C motif) ligand 18 & -2 \\
\hline CCL19 & Chemokine (C-C motif) ligand 19 & -2 \\
\hline CCR2 & Chemokine (C-C motif) receptor 2 & -1.6 \\
\hline CXCR4 & Chemokine (C-X-C motif) receptor 4 & -1.6 \\
\hline \multicolumn{3}{|c|}{ Cytokines and cytokine receptors } \\
\hline D2S448 & $\begin{array}{l}\text { Interleukin-1 receptor antagonist, } \\
\text { melanoma associated gene }\end{array}$ & 1.7 \\
\hline IL1RL1LG & Interleukin 1 receptor-like 1 ligand & 1.6 \\
\hline IL2RG & Interleukin 2 receptor, gamma & -2.4 \\
\hline IL7R & Interleukin 7 receptor & -2.2 \\
\hline IL6R & Interleukin 6 receptor & -2.1 \\
\hline IL21R & Interleukin 21 receptor & -1.9 \\
\hline IL27RA & Interleukin 27 receptor, alpha & -1.9 \\
\hline IL16 & $\begin{array}{l}\text { Interleukin } 16 \text { (lymphocyte } \\
\text { chemoattractant factor) }\end{array}$ & -1.8 \\
\hline IL2RB & Interleukin 2 receptor, beta & -1.6 \\
\hline \multicolumn{3}{|c|}{ Adhesion molecules } \\
\hline NCAM1 & Neural cell adhesion molecule 1 & 2 \\
\hline ITGB3 & $\begin{array}{l}\text { Integrin, beta } 3 \text { (patelet } \\
\text { glycoprotein IIla, CD61) }\end{array}$ & 2 \\
\hline MCAM & Melanoma cell adhesion molecule & 2 \\
\hline EPHAЗ & EphrinA3 & 1.7 \\
\hline SELL & $\begin{array}{l}\text { Selectin L (CD62L, lymphocyte } \\
\text { adhesion molecule 1) }\end{array}$ & -3.7 \\
\hline ICAM1 & $\begin{array}{l}\text { Intercellular adhesion } \\
\text { molecule } 1 \text { (CD54) }\end{array}$ & -1.8 \\
\hline ITGA4 & $\begin{array}{l}\text { Integrin, alpha } 4 \text { (CD49D, alpha } 4 \\
\text { subunit of VLA-4 receptor) }\end{array}$ & -1.7 \\
\hline ITGA1 & Integrin, alpha 1 & 4.2 \\
\hline ITGB5 & Integrin, beta 5 & 2.4 \\
\hline ENPEP & $\begin{array}{l}\text { Glutamyl aminopeptidase } \\
\text { (aminopeptidase A) }\end{array}$ & 2.4 \\
\hline
\end{tabular}

of one of the VEGF receptors, FLT-1, in the GD thyroid. Transcripts of placental growth factor, another angiogenic stimulator, were also increased (Table 4).

\section{Discussion}

AITD is a multistep process initiated by the interaction of genetic and environmental factors. Thyroid samples obtained at surgery in most cases represent the chronic phase of AITD; lymphocytes were accumulated, ectopic lymphoid follicles had formed and, in the case of HT, thyrocytes had disappeared. However, maintenance of the lymphocytic infiltrate in AITD tissues is not static. The presence of activated T-cells in the thyroid (19, 20) and increasing variability of T-cell clones and auto-antibody affinity during the course of AITD $(1,21,22)$, even after treatment, reflects the longstanding active immunological processes in the thyroid. Thus, comparison between HT and GD thyroid transcript patterns within identical genetic background
Table 4 Angiogenesis and apoptosis related transcripts differentially expressed between GD and HT tissue (SLR = signal log ratio: $\geq 1.5$ or $\leq-1.5$; GD:HT).

\begin{tabular}{|c|c|c|}
\hline Gene symbol & Gene description & SLR \\
\hline \multicolumn{3}{|l|}{ Angiogenesis } \\
\hline PGF & $\begin{array}{l}\text { Placental growth factor, vascular } \\
\text { endothelial growth factor-related protein }\end{array}$ & 2.7 \\
\hline VEGF & Vascular endothelial growth factor & 2.6 \\
\hline FLT1 & $\begin{array}{l}\text { Fms-related tyrosine kinase } 1 \text { (vascular } \\
\text { endothelial growth factor/vascular } \\
\text { permeability factor receptor) }\end{array}$ & 1.9 \\
\hline VWF & Von Willebrand factor & 1.9 \\
\hline PDGFRB & $\begin{array}{l}\text { Platelet-derived growth factor receptor, } \\
\text { beta polypeptide }\end{array}$ & 1.8 \\
\hline $\begin{array}{l}\text { VEGFC } \\
\text { Apoptosis }\end{array}$ & Vascular endothelial growth factor C & 1.8 \\
\hline BCL2L2 & BCL2-like 2 & 2.1 \\
\hline BAG1 & BCL2-associated athanogene & 1.7 \\
\hline TNFSF10 & $\begin{array}{l}\text { Tumor necrosis factor (ligand) superfamily, } \\
\text { member 10; TNF-related } \\
\text { apoptosis-inducing ligand (TRAIL) }\end{array}$ & -2.5 \\
\hline TOSO & Regulator of Fas-induced apoptosis & -2.3 \\
\hline CASP3 & $\begin{array}{l}\text { Caspase } 3 \text {, apoptosis-related cysteine } \\
\text { protease }\end{array}$ & -2.1 \\
\hline TRAF1 & TNF receptor-associated factor 1 & -1.9 \\
\hline CASP1 & $\begin{array}{l}\text { Caspase 1, apoptosis-related cysteine } \\
\text { protease (interleukin 1, beta, convertase) }\end{array}$ & -1.7 \\
\hline BIK & BCL2-interacting killer (apoptosis-inducing) & -1.6 \\
\hline
\end{tabular}

and management may give an insight into different immune and remodeling processes. However, comparison between HT and GD transcript expression primarily reflects the varied cellular composition of the lesioned tissue. Thyrocytes were replaced by enlarged lymphocytic infiltrates in HT. Thus, thyrocyte-related transcripts were lower and lymphocyte-related cDNAs higher in HT than in GD. Thyrocytes remain intact in GD, which unsurprisingly showed higher levels of basal membrane component cDNAs than did HT. Increased apoptosis has been proposed as the mechanism for thyroid cell destruction in HT. Besides thyrocytes, lymphocytes located in the ectopic follicles undergo apoptosis during somatic mutation in their immunoglobulin variable-region genes to provide antibodies with higher affinity. Interestingly, we found higher cDNA levels for the major components of the TRAIL/Apo2L, caspase 8 and caspase 3 apoptosis signaling pathway in HT compared with GD. Thus, an alternative pathway killing cells in HT besides that initiated by the activation of the Fas death receptor by binding Fas-ligand (FasL), (reviewed in Salmaso et al. (23)), might be involved. Transcripts of chemokines/chemokine receptors involved in lymphocyte migration into the thyroid and in the maintenance of infiltrates were more heavily expressed in HT than in GD thyroid. We found higher cDNA levels for CCR7 and one of its ligands, CCL19. This chemokine, together with CCL21, enables migration of T-cells into secondary lymphoid tissues or, as in the case of thyroid tissue, into ectopic follicles. Moreover, we have confirmed recent data demonstrating higher expression of 
CXCL12 or its receptor CXCR4 as well as CXCL13 or its receptor CXCR 5 in HT compared with GD thyroids (15, $18,24)$ by microarray and real-time PCR. In addition to chemokines, classical cytokines may reflect ongoing immune processes in AITD. IL-2, INF- $\gamma$ and tumor necrosis factor (TNF)- $\alpha$-secreting Th1 cells stimulated by IL-12 were proposed to be involved in cell-mediated inflammatory reactions as seen in HT. A Th2-type cytokine secretion pattern characterized by IL-4, IL-5, IL-10 and IL-13 should prevail in GD. Here, the absence of many cytokine cDNAs in one or even both thyroid samples was surprising at first sight. However, the role of the Th1/Th2 balance in AITD is still controversial, especially after the publication of data from clinical studies and newly established mouse models (reviewed in Rotondi et al. (25), Dogan et al. (26), and Nagayama et al. (27)). Moreover, older studies have investigated cytokine cDNAs in thyroids using RT-PCR, which enables detection of traces of cytokine mRNAs (2831). If low cytokine mRNA levels reflect protein expression of cytokines, their role during pathogenesis of AIDT remains unclear.

Hypervascularity and increased blood flow in the thyroid is a diagnostic feature in GD $(32,33)$. Microvascular density per follicle is significantly higher in GD tissues than in normal thyroid (34). The mechanism of blood vessel formation - angiogenesis - is modulated by both promoters and inhibitors. In our study, upregulation of the principal promoter of endothelial cell growth and migration, VEGF, and one of its receptors, Flt-1, was seen in the GD tissue. Our data agree with those of Nagura et al. (34).

Until now, there have only been a few studies on monozygotic twins with AITD; one of these twins had either hyperthyroidism or hypothyroidism (3-6, 35, 36). All twins were female. The diagnosis of AITD in older studies was based on measurements of thyroid hormones, and, in some cases, on fine-needle aspirates. The diagnosis of GD in two of the studies was confirmed by the presence of LATS (long-acting thyroid stimulator). In two pairs of twins, the GD patient was TSAb-positive, while TBAbs were detected in the patient with hypothyroidism $(5,6)$. In the case presented here, TBII was only detected in the GD patient, who showed TSAb but not TBAb activity. The HLA phenotype in our twins is not associated with any increased relative risk for Caucasians to develop AITD, although the diagnosis of HT in the mother suggests a family history of AITD. Increased frequency of HLA-DR3 (DRB1*03) and HLADQA $1 * 0501$ haplotypes has been demonstrated in Caucasian GD patients. The relative risk for people with DR3 is approximately $2-4$ (37).

Altogether, comparison of equally managed thyroid tissue from monozygotic twins reflects the ongoing destruction and reconstruction processes within the thyroid at the cellular level. These processes are clearly different between the two clinical forms of AITD, GD and HT.

\section{Acknowledgements}

We would like to thank M Steinert and P Lamesch (formerly Center of Surgery, University of Leipzig; now at the Municipal Hospital Martha-Maria Halle-Dölau and St Georg Municipal Hospital Leipzig respectively) for providing thyroid tissues. The microarray analysis was conducted at the IZKF Leipzig core facility. We are grateful to $\mathrm{P}$ Süptitz, D Sittig and E Schmücking for their technical assistance. This work was supported by a grant from Deutsche Forschungsgemeinschaft (DFG/AU 132-2). K K is supported by IZKF Leipzig (project Z03).

\section{References}

1 Armengol MP, Juan M, Lucas-Martin A, Fernandez-Figueras MT, Jaraquemada D, Gallart T \& Pujol-Borrell R. Thyroid autoimmune disease: demonstration of thyroid antigen-specific B cells and recombination-activating gene expression in chemokine-containing active intrathyroidal germinal centers. American Journal of Pathology $2001159861-873$.

2 Tomer Y, Ban Y, Concepcion E, Barbesino G, Villanueva R, Greenberg DA \& Davies TF. Common and unique susceptibility loci in Graves' and Hashimoto diseases: results of whole genome screening in a data set of 102 multiplex families. American Journal of Human Genetics 200373 736-747.

3 Jayson MI, Doniach D, Benhamou-Glynn N, Roitt IM \& el Kabir DJ. Thyrotoxicosis and Hashimoto goitre in a pair of monozygotic twins with serum long-acting thyroid stimulator. Lancet 19672 $15-18$.

4 Chertow BS, Fidler WJ \& Fariss BL. Graves' disease and Hashimoto's thyroiditis in monozygous twins. Acta Endocrinologica 1973 72 18-24.

5 Ilicki A, Marcus C \& Karlsson FA. Hyperthyroidism and hypothyroidism in monozygotic twins: detection of stimulating and blocking THS receptor antibodies using the FRTL5-cell line. Journal of Endocrinological Investigation 199013 327-331.

6 Tani J, Yoshida K, Fukazawa H, Kiso Y, Sayama N, Mori K, Aizawa Y, Hori H, Nakasato N \& Abe K. Hyperthyroid Graves' disease and primary hypothyroidism caused by TSH receptor antibodies in monozygotic twins: case reports. Endocrine Journal $199845117-121$.

7 Brix TH, Kyvik KO \& Hegedus L. A population-based study of chronic autoimmune hypothyroidism in Danish twins. Journal of Clinical Endocrinology and Metabolism 200085 536-539.

8 Brix TH, Kyvik KO, Christensen K \& Hegedus L. Evidence for a major role of heredity in Graves' disease: a population-based study of two Danish twin cohorts. Journal of Clinical Endocrinology and Metabolism 200186 930-934.

9 Ringold DA, Nicoloff JT, Kesler M, Davis H, Hamilton A \& Mack T. Further evidence for a strong genetic influence on the development of autoimmune thyroid disease: the California twin study. Thyroid $200212647-653$.

10 Strieder TG, Prummel MF, Tijssen JG, Endert E \& Wiersinga WM. Risk factors for and prevalence of thyroid disorders in a cross-sectional study among healthy female relatives of patients with autoimmune thyroid disease. Clinical Endocrinology $2003 \mathbf{5 9}$ 396-401.

11 Prummel MF, Strieder T \& Wiersinga WM. The environment and autoimmune thyroid diseases. European Journal of Endocrinology 2004150 605-618.

12 Schott M, Scherbaum WA \& Morgenthaler NG. Thyrotropin receptor autoantibodies in Graves' disease. Trends in Endocrinology and Metabolism $200516243-248$. 
13 Evans C, Morgenthaler NG, Lee S, Llewellyn DH, Clifton-Bligh R, John R, Lazarus JH, Chatterjee VK \& Ludgate M. Development of a luminescent bioassay for thyroid stimulating antibodies. Journal of Clinical Endocrinology and Metabolism $1999 \mathbf{8 4}$ $374-377$.

14 Jordan NJ, Rinderle C, Ashfield J, Morgenthaler NG, Lazarus J, Ludgate M \& Evans C. A luminescent bioassay for thyroid blocking antibodies. Clinical Endocrinology 200154 355-364.

15 Aust G, Sittig D, Becherer L, Anderegg U, Schütz A, Lamesch P \& Schmücking E. The role of CXCR 5 and its ligand CXCL13 in the compartmentalization of lymphocytes in thyroids affected by Grave's disease. European Journal of Endocrinology $20041 \mathbf{1 5 0}$ $225-234$.

16 Hofmann A, Laue S, Rost A, Scherbaum WA \& Aust G. mRNA levels of MT1-MMP, MMP-2, and MMP-9 and their inhibitors TIMP-2 and TIMP-3 in normal thyrocytes and thyroid carcinoma cell lines. Thyroid $1998 \mathbf{8} 203-214$.

17 Aust G, Crisp M, Bösenberg E, Ludgate M, Weetman AP \& Paschke R. Transcription of thyroid autoantigens in non-expressing tissues. Experimental and Clinical Endocrinology and Diabetes $1998106319-323$.

18 Aust G, Steinert M, Kiessling S, Kamprad M \& Simchen C. Reduced expression of stromal derived factor 1 in autonomous thyroid adenomas and its regulation in thyroid-derived cells. Journal of Clinical Endocrinology and Metabolism 2001863368 -3376.

19 Margolick JB, Weetman AP \& Burman KD. Immunohistochemical analysis of intrathyroidal lymphocytes in Graves' disease: evidence of activated $\mathrm{T}$ cells and production of interferon gamma Clinical Immunology and Immunopathology 198847 208-218.

20 Aust G, Lehmann I, Laue S \& Scherbaum WA. Activated and IFNgamma producing thyroid-derived T cells are detected in Graves' disease, thyroid autonomy as well as in non-toxic multinodular goiter. European Journal of Endocrinology 1996135 60-68.

21 Davies TF. T-cell receptor gene expression in autoimmune thyroid disease: some observations and possible mechanisms. Annals of the New York Academy of Sciences 1995756 331-344.

22 Quaratino S, Badami E, Pang YY, Bartok I, Dyson J, Kioussis D, Londei M \& Maiuri L. Degenerate self-reactive human T-cell receptor causes spontaneous autoimmune disease in mice. Nature Medicine 200410 920-926.

23 Salmaso C, Bagnasco M, Pesce G, Montagna P, Brizzolara R, Altrinetti V, Richiusa P, Galluzzo A \& Giordano C. Regulation of apoptosis in endocrine autoimmunity: insights from Hashimoto's thyroiditis and Graves' disease. Annals of the New York Academy of Sciences $2002966496-501$.

24 Armengol MP, Cardoso-Schmidt CB, Fernandez M, Ferrer X, PujolBorrell R \& Juan M. Chemokines determine local lymphoneogenesis and a reduction of circulating CXCR4(+) T and CCR7 B and T lymphocytes in thyroid autoimmune diseases. Journal of Immunology $20031706320-6328$.

25 Rotondi M, Lazzeri E, Romagnani P \& Serio M. Role for interferongamma inducible chemokines in endocrine autoimmunity: an expanding field. Journal of Endocrinological Investigation 200326 $177-180$

26 Dogan RN, Vasu C, Holterman MJ \& Prabhakar BS. Absence of IL4 , and not suppression of the Th2 response, prevents development of experimental autoimmune Graves' disease. Journal of Іттиnology 2003170 2195-2204.

27 Nagayama Y, Watanabe K, Niwa M, McLachlan SM \& Rapoport B. Schistosoma mansoni and alpha-galactosylceramide: prophylactic effect of Th1 immune suppression in a mouse model of Graves' hyperthyroidism. Journal of Immunology 2004173 2167-2173.

28 Paschke R, Schuppert F, Taton M \& Velu T. Intrathyroidal cytokine gene expression profiles in autoimmune thyroiditis. Journal of Endocrinology 1994141 309-315.

29 Heuer M, Aust G, Ode-Hakim S \& Scherbaum WA. Different cytokine mRNA profiles in Graves' disease, Hashimoto's thyroiditis and non-autoimmune thyroid disorders determined by quantitative reverse transcriptase chain reaction (RT-PCR). Thyroid 19966 97-106.

30 Ajjan RA, Watson PF, McIntosh RS \& Weetman AP. Intrathyroidal cytokine gene expression in Hashimoto's thyroiditis. Clinical and Experimental Immunology $1996 \mathbf{1 0 5} 523-528$.

31 Ajjan RA, Watson PF \& Weetman AP. Detection of IL-12, IL-13, and IL-15 messenger ribonucleic acid in the thyroid of patients with autoimmune thyroid disease. Journal of Clinical Endocrinology and Metabolism 199782 666-669.

32 Sato K. Vascular endothelial growth factors and thyroid disorders. Endocrine Journal 200148 635-646.

33 Wang CY \& Chang TC. Thyroid Doppler ultrasonography and resistive index in the evaluation of the need for ablative or antithyroid drug therapy in Graves' hyperthyroidism. Journal of Formosan Medical Association 2001100 753-757.

34 Nagura S, Katoh R, Miyagi E, Shibuya M \& Kawaoi A. Expression of vascular endothelial growth factor (VEGF) and VEGF receptor-1 (Flt-1) in Graves' disease possibly correlated with increased vascular density. Human Pathology 200132 10-17.

35 Foley TP Jr, Schubert WK, Marnell RT \& McAdams AJ. Chronic lymphocytic thyroiditis and juvenile myxedema in uniovular twins. Journal of Pediatrics 196872 201-207.

36 Townes PL \& Bradford WL. Congenital hypothyroidism and hyperthyroidism in monozygotic twin girls. Journal of Medical Genetics $19718471-477$.

37 Tomer Y, Barbesino G, Greenberg DA, Concepcion E \& Davies TF. Mapping the major susceptibility loci for familial Graves' and Hashimoto's diseases: evidence for genetic heterogeneity and gene interactions. Journal of Clinical Endocrinology and Metabolism $1999844656-4664$.

Received 29 July 2005

Accepted 26 September 2005 